\title{
Development Trends and Strategic Research for China's Energy Engineering Science and Technology to 2035
}

\author{
Zhang Bo ${ }^{1,2}$, Guo Danning ${ }^{2}$, Peng Suping ${ }^{1}$ \\ 1. State Key Laboratory of Coal Resources and Safe Mining, China University of Mining \& Technology (Beijing), Beijing 100083, China \\ 2. School of Management, China University of Mining \& Technology (Beijing), Beijing 100083, China
}

\begin{abstract}
In the next 20 years, science and technology innovation in energy will bring about profound reform in the characteristics and patterns of China's energy industries. This study analyzes the basic background and related strategic demands of China's energy development, describes the present situation, and identifies existing problems in energy engineering science and technology. It also proposes medium- and long-term development strategies for China's energy engineering science and technology, including overall conception, main tasks, and important technical directions. Trends, impacts, and a possible blueprint for energy engineering science and technology to 2035 are predicted. These results can contribute to the scientific establishment of innovation systems in energy engineering science and technology, based on China's energy resources and development conditions. Furthermore, they can contribute to the formation of China's strategic countermeasures in energy engineering science and technology to 2035 by considering the country's overall and long-term development demands.
\end{abstract}

Keywords: energy engineering science and technology; trend analysis; technical direction; to 2035; development strategy

\section{Introduction}

The world is experiencing rapid industrial, economic, and social changes. Underpinned by a new round of technological and industrial revolution, the trend toward energy diversification, clean energy, and a low-carbon economy is gaining momentum. The energy landscape is undergoing profound changes as energy restructuring accelerates [1]. Technological progress has a huge impact on the structure of global energy supply, resulting in greater supply, an extended timescale for the depletion of fossil-based energy resources [2], and a revitalized competitive edge for fossil energy produced and utilized in a clean and efficient manner. Fast-growing non-fossil fuels help diversify the energy portfolio and spur a transition toward energy production and consumption. Distributed energy systems emerge as renew- able energy grows rapidly. Power generation using renewable energy sources increasingly requires grid connection. Meanwhile, electrical grids, including large grids and microgrids, are becoming smarter. The widespread adoption of emerging energy technologies is expected to give rise to new business clusters and sources of growth on many fronts, such as the clean and efficient use of fossil fuels, marine and unconventional oil and gas development, the safe use of nuclear energy, the large-scale development and utilization of renewable energy, the deployment of smart grids, large-scale energy storage and distributed energy usage, and the adoption of high-performance energy equipment and key materials [3]. Energy technology innovation is thus becoming the driving force behind the transformation of the energy industry.

Resources, the environment, and the economy will remain the

Received date: 12 december 2016; revised date: 20 December 2016

Corresponding author: Zhang Bo, China University of Mining \& Technology (Beijing), Associate Professor. Major research field is energy economics and policy. Email: zhangbo@cumtb.edu.cn

Funding program: CAE Advisory Project “Research on China's Engineering Science and Technology Development Strategy 2035” (2015-ZD-14)

Chinese version: Strategic Study of CAE 2017, 19 (1): 064-072

Cited item: Zhang Bo et al. Development Trends and Strategic Research for China's Energy Engineering Science and Technology to 2035. Strategic Study of CAE, https://doi.org/10.15302/J-SSCAE-2017.01.010 
major challenges to the world's energy development in the next two decades. Developed countries and emerging economies will both continue to introduce policies to accelerate the development and commercialization of new energy technologies to seek an advantage in the new round of industry growth driven by green and low-carbon energy technologies. It is a long-term task for China to promote the revolution in the production and consumption of energy and ensure national energy security [4]. Science and technology (S\&T) is the key factor to trigger and bolster the energy revolution in China [5]. The long-term, healthy, and sustainable development of a large and complex energy system will be driven and underpinned by technological innovation. Therefore, it is important to understand domestic and global trends in energy development as well as strategic energy engineering needs when formulating the future innovation system required by China. Such foresight will help identify the key areas, technological priorities, and measures needed to formulate China's medium- and long-term energy engineering development plans and initiatives.

\section{An overview of China's energy industry and engineering S\&T needs}

\subsection{An overview of China's energy industry}

China is the world's largest energy producer and consumer. The rapid development of its energy industry has made important contributions to the national economy and social development. However, extensive growth and demand-oriented energy supply have resulted in the rapidly expanding production and consumption of energy resources. In 2015, China accounted for $23 \%$ of global energy consumption and contributed $43 \%$ to its growth. Although the $1.5 \%$ increase in that year marked the lowest growth in nearly 20 years, China has been the leading contributor to global energy consumption growth for 15 consecutive years [6]. Meanwhile, the overall size and rate of growth vary considerably among the types of energy sources, presenting a complex picture of differences and challenges.

China's resource endowment is widely imbalanced. The country has a large amount of fossil energy resources, mostly coal. Moreover, although reserves of oil and gas are relatively insufficient, there is great potential in unconventional hydrocarbon resources. However, unlike energy-abundant economies, China's reserves per capita are relatively low, characterized by a shortage of high-quality green resources, geologically and technologically challenging conditions in the development of coal, oil, and gas reserves, and inadequate prospecting of and a lack of economic efficiency for unconventional resources [7]. Most of the renewable energy resources suitable for large-scale development are found in the western region far from load centers. Indeed, the geographical disconnection between the production and consumption of energy is noticeable. Resource endowment is badly out of line with water needs, the ecological environment, and economic growth and there is a long-standing need for large-scale, long-distance energy transportation.

Far from being produced and utilized in a highly sophisticated manner, coal and other conventional fossil fuels have too large a share of China's primary energy mix. China is the world's largest coal producer and consumer. Coal, as the main source of energy, makes an important contribution to economic and social development as well as to energy security. However, from the perspective of production, large coalmines are being built despite the issue of massive overcapacity and the adoption of clean coal technology is limited; from the perspective of consumption, there is considerable pressure on controlling air pollution, reducing emissions and protecting the environment, and clean and efficient use is yet to be increased. As a significant producer and consumer of oil and gas, the commercial exploitation of unconventional resources is taking place in China. However, domestic oil and gas resources are insufficient to meet the huge need for energy, as it is increasingly difficult to sustain a steady growth rate of oil production, and gas production is slowing because of a decline in deposit grades. All this leads to soaring oil and gas dependency rates.

Despite its rapid development in China, non-fossil energy has low economies of scale and plays a limited role in replacing conventional fossil fuels. Nuclear power is a high-tech sector in which China is poised to gain a competitive edge, and the country is well prepared to embrace large-scale nuclear power generation with its proprietary Generation III nuclear power unit, equipment, and nuclear fuels. However, during energy restructuring, the role of nuclear power is limited because of the size of the installed capacity. China is the world's largest renewable power generator with its solar power and wind power capacities growing rapidly. Indeed, as the world's leading wind power market, China has the largest new capacity installed for wind power. It is also the world's largest producer of solar power with remarkably improved competitiveness in power generation. However, a number of issues concerning equipment manufacturing, operation and management, and power utilization have yet to be addressed. China has the world's largest power system for large-scale distribution and optimization across the country. Smart grids are making headway; however, renewable energy is yet to be improved in terms of its supporting facilities, economic benefits, and the reliability of its transmission and distribution.

Although the energy supply constraints on China's economic development have been alleviated, environmental protection and climate change have become a major concern in the country's energy development. Energy efficiency is low, the percentage of electricity in end-use energy consumption is small, and per capita electricity consumption is far below that of advanced economies. Overall, there is huge energy-saving potential. To meet energy demand and ensure national energy security, optimize the structure of energy production and consumption, improve 
the ecological environment and cope with climate change, and cultivate new economic growth momentum, there is therefore an urgent need for energy engineering S\&T innovations.

\subsection{Current state of energy engineering development and pending issues}

Since the 12th Five-Year Plan, China has picked up the pace in bolstering its research and development (R\&D) efforts and promoting industrialization in the energy sector. Proprietary innovations together with foreign technologies that have been imported, adapted, and re-innovated continue to enhance technological competency and innovation in various areas. China has become a leading player in a few domains of energy [5]. For example, it is taking the lead in coalmine construction and mining technology, with major breakthroughs in the clean and efficient processing and use of coal, such as ultra-low emissions from power generation, advanced coal-fired power generation, and coal-to-chemicals technologies. In the oil and gas sector, China leads the way in exploration theories and techniques, controlled water injection in mature fields, and chemical flooding for enhanced oil recovery, with significant progress in the exploration and production of deepwater drilling, tight gas, shale gas, tight oil, and coal-bed methane. Further, the nuclear power industry has improved its ability to innovate, mastering most Generation III nuclear power technologies and launching its own large pressurized water reactors. The renewable energy boom is seeing new generating capacity installed exceeding that for fossil fuels as China keeps pace with the world market in solar power generation and begins to lead the design and manufacture of large turbine blades. In addition, excellent results have been achieved in ultra-high voltage (UHV)/flexible electricity transmission, large grid management and power dispatching and renewable energy generation, while a good foundation has been provided for R\&D, equipment manufacturing, and the adoption of smart grids. Finally, emerging sectors such as distributed power, energy storage, energy-saving technology, and fuel cells are making progress.

Meanwhile, China is faced with a number of issues in the development of energy technology. Its innovation mechanisms in energy exploration, processing, utilization, and equipment manufacturing are outdated. The coal industry needs to become cleaner and more efficient, which requires advanced coal technology to be developed and promoted. Technological constraints on the development of unconventional oil and gas resources are yet to be overcome, and the commercial exploitation of unconventional and deepwater deposits still has a long way to go. The installed nuclear power capacity is yet to be expanded and nuclear technology needs to become safer and more efficient. Moreover, innovation in renewable energy technology is inadequate, with core equipment for photovoltaic (PV) cells, concentrated solar power, and geothermal power largely dependent on foreign imports, issues such as grid connection and power utilization yet to be addressed, and smart grids subject to a number of technology and market constraints. Meanwhile, major energy projects rely heavily on imported equipment [5]. With respect to technological forefronts, R\&D and industrialization efforts need to be strengthened in areas such as ultra-low emissions from coal-fired power generation, integrated gasification combined cycle (IGCC)/integrated gasification fuel cell (IGFC), micro-earthquake, digital oilfields, volume fracturing of horizontal wells, deepwater and unconventional exploration and production, UHV, Generations III and IV nuclear power, smart grids, energy-saving and new energy vehicles, $\mathrm{PV}$, wind power, fuel cells, and large-scale energy storage.

\section{Development strategies for energy engineering S\&T}

\subsection{Guiding idea}

The medium- and long-term development of energy engineering S\&T in China should be in line with the current stage of socioeconomic development and national strategic priorities. Given the irreplaceable role of fossil fuels in China's energy system, it is important to cut high-carbon energy by using clean and efficient energy technologies; smart grids, the energy Internet, and energy-saving innovations will help boost the percentage of electricity in end-use energy consumption and improve significantly the overall efficiency of the energy system to revolutionize the energy-saving and efficient energy system [8]. Therefore, bearing in mind the guiding rules for the development of energy technologies, green production technologies and clean, lowcarbon, and intensive energy utilization options will be promoted, with priority given to energy-saving and emissions reduction technologies. A complete value chain will be created, comprising innovation, R\&D, commercialization, marketing, and application; new energy technologies and equipment solutions will be identified; and R\&D and domestic equipment manufacturing will be bolstered through a series of demonstration projects. The fundamental purpose is to establish an internationally competitive energy engineering S\&T system in line with the development needs and resource characteristics of China to reshape its energy system, allowing a shift from a simple clean and efficient mode of energy exploitation and utilization to a green and low-carbon one, and eventually to a smart and diversified energy system. Overall, the country needs energy products and services that are eco-friendly and meet the needs for sustainable energy development as well as facilitate the transformation from a major energy producer/consumer to an energy superpower.

\subsection{Key strategic priorities [9]}

\subsubsection{Coal engineering}

Coal transformation will focus on eco-friendly mining and 
low-carbon coal-fired power generation. First, safe and efficient mining remains the key issue in coal development. Water conservation and the ecological restoration of surface disturbances in the main coal-producing areas of western China represent an important engineering topic. Meanwhile, a number of technological challenges are yet to be tackled, including precise exploration; safe and efficient coal mining in difficult coal seams; the coordinated mining of coal, uranium, oil and gas, and other associated minerals; and intelligent mining and smart mines. Second, it is important that coal is used in an efficient, energy-saving, water-saving, and clean manner. The research and development of next-generation clean, high-efficiency, and near zero emissions technology will pick up pace, and curbing carbon dioxide emissions will remain a major challenge [10]. In coal-fired power generation, a series of technical difficulties need to be addressed, including $700^{\circ} \mathrm{C}$ ultra-supercritical coal-based power generation; next-generation IGCC and IGFC power generation and cogeneration; near zero emissions; and carbon capture, utilization, and storage (CCUS). Third, large, highly industrialized coal-to-chemicals plants represent a trend in coal conversion. Technological breakthroughs targeting processes, catalysts, and large equipment are needed in coal-based cogeneration, coal gasification, catalytic gasification, and coal hydrogenation. Water consumption and wastewater recycling problems in coal transformation must be solved. A sophisticated approach to coal development and a clean and efficient mode for coal consumption will be developed. In particular, a low-carbon, efficient, and clean coal-fired power generation system will achieve an efficiency rate above $50 \%$; large coal-fired plants will be equipped with CCUS to ensure near zero emissions.

\subsubsection{Oil and gas engineering}

In the oil and gas industry, deepwater drilling, smart systems, and integrated solutions shape the trend. Deepwater drilling, conventional oil and gas resources, high-water cut and highrecovery ratio oilfields, and complex oil and gas reservoirs require the development and adoption of suitable equipment and techniques. This includes enhanced oil recovery (EOR) technologies to improve efficiency, lower the costs of conventional/ non-conventional oil and gas activities and ensure long-term steady oil production, sustained growth in natural gas production, and successful overseas operations. First, technological efforts should focus on precise exploration and the shift from conventional to unconventional exploration. Second, the technical issues to be addressed include geological theories, high-precision imaging, ultra-deep drilling and directional drilling, and high-end equipment. Third, EOR technologies for mature, low-permeability, and heavy oil fields and supporting techniques for complex and deepwater drilling should be developed. Fourth, reservoir stimulation techniques, low-cost horizontal drilling, and eco-friendly technologies for a range of unconventional oil and gas resources are needed. Focus will be maintained on technological forefronts such as deep-well, deepwater, unconventional drilling, and EOR. Moreover, proactive R\&D efforts for impactful and disruptive technologies such as deepwater drilling and completion, the exploitation of gas hydrates, and nanorobotics are needed. It is important to achieve a leading position in EOR techniques to ensure low-permeability and ultra-low-permeability clastic reservoirs, commercialize tight oil EOR techniques, promote the adoption of digital basin/digital oilfield technology, enable the large-scale development of deep shale gas and complex coal-bed methane, and start the commercial trial production of gas hydrates, with the overall technological strengths brought to an internationally leading level.

\subsubsection{Nuclear energy engineering}

The safety and cross-industry sustainability of nuclear energy is emphasized worldwide. Generation III reactors have become the mainstream for nuclear plants, while Generation IV technologies are underway. Small and medium-sized modular reactors are gaining wide attention for their versatility in the distributed network environment. Advanced nuclear fuels and recycling technologies are emerging. The license renewal of nuclear power plants is also an important trend [11]. China's nuclear energy engineering development will center on nuclear power generation, with technological breakthroughs targeting advanced techniques, equipment and nuclear fuel solutions, and applications to eliminate the large-scale release of radioactivity. First, technological and management measures for the safe operation and maintenance of nuclear power plants will be studied to ensure operational safety and extend service life. These studies will cover operation and maintenance, emergency response, high-performance and long-lasting fuels, aging and life extension, advanced monitoring, and digital nuclear power plants. Second, proprietary advanced pressurized water reactor projects will be built to meet the higher nuclear safety requirements. Third, a plan for R\&D efforts on Generation IV reactors and future nuclear energy technology will be developed. Fourth, the commercial application of nuclear energy in non-electricity areas such as cogeneration, centralized heating, hydrogen production, and desalination will be promoted. Fifth, a closed nuclear fuel cycle will be created in accordance with China's strategies and policies for nuclear energy development. Sixth, to eliminate the large-scale release of radioactive waste, fast reactors (acceleratordriven subcritical nuclear reactors) or transmutation systems will be used to enable the transmutation treatment of radioactive waste before solidification and geological treatment. Research on glassification and deep geological disposal techniques for the treatment of radioactive waste will be carried out. The purpose is to explore and use accident-resistant fuels to operate nuclear power plants to enhance their inherent security. Generation IV reactor demonstration projects will be sped up to achieve a large-scale, versatile, and sustainable pattern for nuclear power generation. 


\subsubsection{Renewable energy engineering}

"Large scale, high efficiency, and low cost" represents the trend of renewable energy development. An integrated approach to the utilization of renewable energy will be adopted to encourage a mix of complementary energy sources and the adoption of combined cooling, heat and power (CCHP) cogeneration. There is an urgent need to improve the efficiency of energy conversion, reduce the environmental impact of renewable energy products, and bolster the overall technical level of renewable energy use. First, PV power generation will continue to become more efficient and cost-effective. R\&D and commercialization efforts will focus on eco-friendly components (i.e., crystalline silicon solar cells, thin film solar cells, and calcium carbonate solar cells) with a conversion efficiency rate greater than $25 \%$. A wider range of safer, more reliable PV modules will be developed and research on smart microgrid technology for building-integrated photovoltaics will be ramped up. Second, solar thermal energy technology will target high thermal parameters, high efficiency, base-load generation, and long-term thermal storage, especially core technologies such as high-temperature, pressurized heat absorbers and heat storage solutions. Megawatt third-generation power generation demonstration systems will be built. Lowtemperature cooling techniques, large-capacity heat storage materials, and heat transfer/storage methods will be identified. Technological breakthroughs and example applications for low-temperature solar cooling, large-scale solar heating, and medium-temperature heat collection will be promoted. Third, largescale, smart, and highly reliable wind power generators will become larger, smarter, and more reliable, with offshore wind power and high-altitude wind power on the agenda [5]. $10 \mathrm{MW}$ largescale permanent magnet synchronous turbines, $10 \mathrm{MW}$ doubly-fed speed-up turbines, and $3 \mathrm{MW}+$ low-speed turbines working at low wind speeds will be developed. Exploratory research on highaltitude (6000-12000 m) wind turbines will be carried out. Offshore wind farm technologies will be developed and deployed. Other research topics include wind power big data, the design of wind farms, and the optimization of operations. Fourth, in the field of biomass energy, technological options for biomass conversion, clean production and efficient utilization, the genetic engineering of energy plants, and biomass oil purification and production will be explored. Waste-to-energy technologies using waste from agriculture, forestry, and animal husbandry will be developed, targeting technical issues in clean conversion, low-cost separation and purification, and scale-up engineering for biodiesel, fuel alcohol, pyrolysis oil, synthetic oil, and other biomass liquid fuels. Algae also represent an important direction of biomass energy. Fifth, the focus of hydropower development is on the management of hydropower operations, including the optimal operation of cascaded hydropower systems, safety management and risk mitigation of reservoirs and dams, and ultra-high-voltage direct-current (UHVDC) hydroelectricity transmission and peak shift. Research on technology packages for large-scale, interconnected hydropower management will be carried out. Sixth, in the field of geothermal energy, two common issues are to be tackled: artificial splitting and fracturing techniques and anti-corrosion anti-scaling techniques for geothermal fluids. R\&D efforts on enhanced geothermal generation and low-temperature geothermal heating and cooling will be sped up. Seventh, the sources and uses of hydrogen fuels will be expanded. From fossil fuels to renewable energy, physical storage to hydrogen carriers, chemical hydrogen to hydrogen-led carbon-free energy, integrated research efforts will be pursued to create a hydrogen energy system for eco-friendly production and the efficient storage and use of hydrogen. Natural gas/ hydrogen transportation solutions and flexible-fuel burners will be developed. The technical barriers to the use of fuel cells in distributed power generation will be overcome. Eighth, technical issues concerning efficiency, reliability, cost, and environmental impact in the production and use of marine energy will be addressed. Key technologies for wave power generation, tidal farms, and desalination will be developed and commercialized.

\subsubsection{Power engineering}

The global development of power engineering is characterized by safety, reliability, cost-effectiveness, and smart technology. Emphasis will placed be on smart grids, the grid integration of large-capacity renewable energy sources, distributed microgrid for renewable energy, direct current (DC) power grids, and alternating current/direct current (AC-DC) power grids. Technical barriers to the grid integration of large-capacity renewable energy sources will be overcome to enable largecapacity, long-distance grid integration. Internet-based interactive grid technologies will be developed to turn power grids into energy-sharing platforms. The smart grid is the key factor to the development of power systems. Flexible power transmission and coordination technologies will be promoted to improve grid stability and operating efficiency. Distributed power generation, microgrid, demand response, and flexible energy systems will see wider application. Technological breakthroughs in largescale power storage are needed. A series of power engineering advancements will be achieved, including integrated largescale renewable energy absorption solutions, high-voltage highcapacity flexible DC transmission and grid integration systems, ultra-long-distance $\pm 1100 \mathrm{kV}$ UHVDC transmission, and smart power systems for smart cities.

\subsection{Technology priorities}

Taking into account such factors as technological innovation, technology potential and readiness, and market demand, the key energy engineering S\&T topics for 2035 in the coal, oil and gas, nuclear energy, electricity, and renewable energy sectors are (1) clean and efficient technologies for the development and utilization of fossil energy sources, (2) exploration and production technologies for unconventional and deepwater oil and gas 
resources, (3) proprietary nuclear power generation technologies and nuclear waste treatment technologies, (4) smart grid and energy storage technologies, and (5) technologies for large-scale renewable energy utilization. These main technology priorities are shown in Table 1 [9]. In addition, the basic research, new materials, and IT infrastructure that underpin the development of energy engineering will be promoted.

\section{Impact of energy engineering technologies and outlook for 2035}

In the next two decades, the urbanization process in China will undergo a fundamental shift characterized by the completion of industrialization and profound change in production and consumption patterns. Demand for energy resources will remain

Table 1. Engineering technology priorities in the field of energy for 2035.

\begin{tabular}{|c|c|c|c|c|}
\hline Coal & Oil and gas & Nuclear energy & Electricity & Renewable energy \\
\hline $\begin{array}{l}\text { 1. Geological evaluation and } \\
\text { survey technologies for coal } \\
\text { mining }\end{array}$ & $\begin{array}{l}\text { 1. Big data-based digital } \\
\text { basin and estimation } \\
\text { technologies of remaining } \\
\text { resources }\end{array}$ & $\begin{array}{l}\text { 1. Domestic designed } \\
\text { integrated large fuel- } \\
\text { recycling commercial fast } \\
\text { reactors technologies }\end{array}$ & $\begin{array}{l}\text { 1. High-voltage high- } \\
\text { capacity flexible DC } \\
\text { transmission technologies }\end{array}$ & $\begin{array}{l}\text { 1. Efficient, eco-friendly PV } \\
\text { materials technologies }\end{array}$ \\
\hline $\begin{array}{l}\text { 2. Deep mining technologies } \\
\text { and safe mining technologies } \\
\text { for mega coalmines }\end{array}$ & $\begin{array}{l}\text { 2. Nanorobotics technology } \\
\text { for oil and gas fast drilling }\end{array}$ & $\begin{array}{l}\text { 2. Accident-resistant fuel } \\
\text { component technology }\end{array}$ & $\begin{array}{l}\text { 2. Large-scale electricity } \\
\text { storage techniques }\end{array}$ & $\begin{array}{l}\text { 2. Key technologies for } \\
\text { large-scale medium-high } \\
\text { speed permanent-magnet } \\
\text { wind turbines }\end{array}$ \\
\hline $\begin{array}{l}\text { 3. Coal washing and quality } \\
\text { improvement technologies }\end{array}$ & $\begin{array}{l}\text { 3. Wideband, wide- } \\
\text { azimuth, and high coverage } \\
\text { geophysical exploration } \\
\text { techniques }\end{array}$ & $\begin{array}{l}\text { 3. Technologies for the } \\
\text { elimination of the large- } \\
\text { scale release of radioactivity }\end{array}$ & $\begin{array}{l}\text { 3. Interactive technologies } \\
\text { for large-scale vehicle-- } \\
\text { network integration }\end{array}$ & $\begin{array}{l}\text { 3. Waste-to-energy } \\
\text { technologies using waste } \\
\text { from agriculture, forestry, } \\
\text { and animal husbandry }\end{array}$ \\
\hline $\begin{array}{l}\text { 4. Coal mining and } \\
\text { environmental protection } \\
\text { technologies }\end{array}$ & $\begin{array}{l}\text { 4. Clean and efficient } \\
\text { integrated fracturing and } \\
\text { flooding solutions for low- } \\
\text { grade and unconventional } \\
\text { oil and gas resources }\end{array}$ & $\begin{array}{l}\text { 4. Comprehensive } \\
\text { development technologies } \\
\text { for nonconventional } \\
\text { uranium resources }\end{array}$ & $\begin{array}{l}\text { 4. User-grid interactive } \\
\text { technologies }\end{array}$ & $\begin{array}{l}\text { 4. Enhanced geothermal } \\
\text { generation technologies }\end{array}$ \\
\hline $\begin{array}{l}\text { 5. Integrated smart mining } \\
\text { for coal and associated } \\
\text { resources }\end{array}$ & $\begin{array}{l}\text { 5. Real-time measurement, } \\
\text { evaluation, and integrated } \\
\text { smart logging while drilling } \\
\text { (LWD) techniques }\end{array}$ & $\begin{array}{l}\text { 5. Deep geological disposal } \\
\text { techniques for highly } \\
\text { radioactive waste }\end{array}$ & $\begin{array}{l}\text { 5. Smart grid-based energy } \\
\text { systems }\end{array}$ & $\begin{array}{l}\text { 5. Key technologies for } \\
\text { large-scale multi-feed } \\
\text { UHVDC transmission and } \\
\text { peak shift }\end{array}$ \\
\hline $\begin{array}{l}\text { 6. Next-generation IGCC } \\
\text { and IGFC generation and } \\
\text { cogeneration technologies }\end{array}$ & $\begin{array}{l}\text { 6. Real-time, intelligent, } \\
\text { optimized drilling } \\
\text { (automated drilling) } \\
\text { techniques }\end{array}$ & $\begin{array}{l}\text { 6. Nuclear fuel reprocessing } \\
\text { techniques for advanced } \\
\text { nuclear energy systems }\end{array}$ & $\begin{array}{l}\text { 6. High-voltage, large-power } \\
\text { electrical and electronic } \\
\text { devices }\end{array}$ & $\begin{array}{l}\text { 6. Technologies for } \\
\text { producing hydrogen by } \\
\text { large-scale electrolysis } \\
\text { of water using renewable } \\
\text { energy }\end{array}$ \\
\hline $\begin{array}{l}\text { 7. } 700^{\circ} \mathrm{C} \text { ultra-supercritical } \\
\text { coal-based power generation } \\
\text { techniques }\end{array}$ & $\begin{array}{l}\text { 7. Non-hydraulic fracturing } \\
\text { techniques }\end{array}$ & $\begin{array}{l}\text { 7. Laser isotope separation } \\
\text { techniques using } \\
\text { condensation repression }\end{array}$ & $\begin{array}{l}\text { 7. High-temperature } \\
\text { superconducting generators } \\
\text { and its application } \\
\text { technologies }\end{array}$ & $\begin{array}{l}\text { 7. High-efficiency solar } \\
\text { concentrator and heliostat } \\
\text { field design techniques }\end{array}$ \\
\hline $\begin{array}{l}\text { 9. Gradation-based coal } \\
\text { conversion and utilization } \\
\text { techniques }\end{array}$ & $\begin{array}{l}\text { 9. Reservoir forming } \\
\text { theories and efficient } \\
\text { exploitation technologies } \\
\text { for ultra-deep oil and gas } \\
\text { reservoirs }\end{array}$ & $\begin{array}{l}\text { 9. Z-pinch driven fusion- } \\
\text { fission hybrid reactors } \\
\text { technologies }\end{array}$ & & $\begin{array}{l}\text { 9. Key technologies for } \\
\text { large-scale direct drive } \\
\text { permanent-magnet wind } \\
\text { turbine generators }\end{array}$ \\
\hline \multirow[t]{3}{*}{$\begin{array}{l}\text { 10. Advanced carbon } \\
\text { dioxide capture, utilization, } \\
\text { and storage technologies }\end{array}$} & $\begin{array}{l}\text { 10. Deepwater drilling and } \\
\text { completion, emergency } \\
\text { response technology, and } \\
\text { equipment }\end{array}$ & $\begin{array}{l}\text { 10. Fully intelligent, } \\
\text { integrated, compact, } \\
\text { modular reactors } \\
\text { technologies }\end{array}$ & & $\begin{array}{l}\text { 10. Low-speed wind turbine } \\
\text { technologies }\end{array}$ \\
\hline & $\begin{array}{l}\text { 11. Rig-free exploration } \\
\text { techniques }\end{array}$ & $\begin{array}{l}\text { 11. Hydrogen production } \\
\text { from nuclear energy and } \\
\text { power generation techniques } \\
\text { using helium turbines }\end{array}$ & & $\begin{array}{l}\text { 11. High-reliability smart } \\
\text { microgrid technology } \\
\text { for building-integrated } \\
\text { photovoltaics }\end{array}$ \\
\hline & $\begin{array}{l}\text { 12. Large-scale efficient } \\
\text { exploration and production } \\
\text { technologies of coal-bed } \\
\text { methane and shale gas }\end{array}$ & $\begin{array}{l}\text { 12. In-service equipment } \\
\text { monitoring, maintenance } \\
\text { and evaluation technologies } \\
\text { for operating high } \\
\text { radioactive reactors }\end{array}$ & & \\
\hline
\end{tabular}


strong as traditional industry and infrastructure construction upgrades. A substantial increase in demand for new technologies will be seen in the renewable energy, nuclear energy, natural gas, and carbon emission reduction sectors. Although demand for energy will continue to grow as a whole, energy growth will become less closely correlated with economic growth because of economic development and efficiency improvement. By 2035, fossil fuels will continue to play a major role in the energy mix despite the challenges to the traditional fossil fuel-based energy structure. Meanwhile, renewable energy will maintain strong momentum, with non-fossil energy and natural gas accounting for increasing proportions of end-use energy consumption as well as primary and secondary energy sources. The pattern of energy growth will become intensive rather than extensive and the role of energy in economic growth will be more ecoresponsible and climate-friendly. While pursuing quality and sustainability, the energy industry will experience profound changes both in its forms and in its characteristics [12,13], entering a new era characterized by low-carbon development, smart technology, and diversification.

\subsection{Energy production}

Conventional fossil fuel energy supply and intelligent exploration and production will be greatly boosted. Technological breakthroughs and the wide adoption of technologies to evaluate clean coal resources, the precision production of energy, transparent geophysics with integrated detection, smart mines, the development of unconventional oil and gas resources, deep-well exploration and production, the development of complex reservoirs, and EOR will significantly bolster the safety, efficiency, and synergy of energy development. China's peak for coal mining is approaching, while conventional oil production remains steady. Unconventional oil and gas technology may see a major breakthrough, and unconventional and deepwater oil and gas resources, coal-to-chemicals, and bio-fuels as alternative energy sources will greatly change the landscape of oil and gas supply. Electricity generation will continue to grow in the long term. Renewable energy such as wind power and photovoltaics will account for a larger proportion. Renewable and nuclear power generation will lead to a fundamental change in the structure of power sources. Non-fossil fuel energy will dominate the newly increased energy and electricity generation. The goal of nonfossil fuels accounting for $20 \%$ of the primary energy structure by 2030 is likely to be achieved ahead of schedule.

\subsection{Energy consumption}

While total energy consumption will increase, the structure of energy consumption will continue to be optimized. End-use energy and electricity structures will improve significantly. Coal use, mainly concentrated in power generation, will fall slowly.
Oil consumption will remain stable as a whole. Natural gas consumption will grow remarkably. Access to energy and electricity in both urban and rural areas will be significantly improved. For electricity consumption, the emergence of load demand response, smart building, smart appliance, and electric vehicle technologies will allow interactions between end-users and power grids and meet the need for diversified energy. Smart grids will raise energy efficiency, enable the optimized allocation of energy resources, improve the cost-effectiveness of energy transmission, meet the needs of diversified and interactive power consumption, and ultimately bring about a fundamental change in end-use energy consumption. Energy-saving regulations and measures will be developed. Smart manufacturing will further explore the energy-saving potential of industrial energy consumption. Smart building systems will optimize the energy efficiency of buildings and reduce energy consumption. Buildings will be equipped with intelligent control systems and interfaced with smart grids and distributed energy systems. Smart transportation technology will lead to a revolution in transport modes as well as the energy dissipation structure of vehicles [2]. Smart manufacturing, smart building, and smart transportation will in turn give rise to a structural change on the supply side. The interactive mechanism between end-users and power grids will greatly improve power consumption in end-use and energy efficiency, while offering new options for the better utilization of grid assets.

\subsection{Industrial development and industrial competitiveness}

The industrial development framework will undergo profound changes, leading to an overall improvement in the technological strengths and an internationally leading position in many energy sectors, which will in turn reshape the geopolitical landscape in the global energy market. Coal production will continue to be mainly concentrated in Shanxi, Shaanxi, Inner Mongolia, Ningxia, and Northern Xinjiang. Oil and gas production growth will derive largely from deepwater and unconventional resources. The power grid system will undergo a major transformation, resulting in the largest and most complex hybrid power grid in the world comprising UHV transmission networks and microgrids. The trendsetting energy interconnection system will bolster large-scale, long-distance power transmission and coal transportation. Large-scale renewable electricity will be absorbed and distributed locally in a cost-effective manner to bridge the geographical distance between energy production and consumption. The costs of wind power and solar power are expected to fall to a similar level to those for power generation using conventional energy sources. Non-fossil energy will become as competitive as conventional fossil fuels. Technological advancements in energy production and consumption will enjoy an internationally leading position, with the emergence of a number of globally competitive energy companies. Cross-border, intercontinental power grid connection will be promoted, endowing China with a 
growing voice in the global energy market and helping pave the path to the commanding heights of emerging energy industries [14].

\subsection{Environmental protection and climate change}

The clean and efficient use of fossil energy and growing supply capacity of non-fossil energy will contribute to clean, low-carbon energy development. Clean and efficient coal production will be achieved, with a continuous improvement in the overall efficiency of coal-fired power generation and a further decline in the amount of coal used in power generation. The wide adoption of emissions control technologies and CCUS will significantly reduce the environmental impact across the coal industry. Low-carbon energy sources such as natural gas, nuclear energy, and renewable energy will play a more important role. Carbon emissions will peak before 2030. Technological advancements in renewable energy will further reduce the life-cycle environmental impact. In addition, the efficiency improvement in manufacturing, construction, transportation, and lighting will continue to contribute to energy-saving and emissions reduction efforts through the "amplifier effect" of end-use energy consumption.

\subsection{Energy industry}

The mechanisms for the planning, design, and operation of separate components in the existing energy system will be modified to create an integrated energy system that will reshape energy production and consumption in China. The energy system for 2035 will be an intelligent, integrated network comprising a variety of energy sources, including electricity, gas, water, heating power, and energy storage and combining the supply of electricity, gas, heating/cooling, and hydrogen with public infrastructure systems such as transportation, information, and healthcare. A coordinated and scientific approach will be adopted to streamline the production, transmission, distribution, conversion, storage, and consumption of energy in the system, enabling integrated, grade-based, and efficient production as well as the supply and utilization of energy. Smart grids will serve as the main energy network, with pan-energy networks and microgrids playing a supporting role in local neighborhoods, parks, urban complexes, and urban districts. The integration of centralized and distributed energy systems will contribute to a sophisticated level of the energy Internet [2]. Meanwhile, the coordinated development of energy, the ecosystem, technology, and the socioeconomic system will be promoted. The transformation of the energy industry will benefit from financial innovations and advancements in other sectors, thereby improving the exploration, extraction, conversion, storage, sharing, and application of energy sources. Energy is for everyone to explore, control, gain access to, and benefit from. Low-carbon and intelligent energy production and consumption will shape the outlook of energy, the economy, and society by 2035 .

\section{Conclusions}

Energy engineering S\&T innovations are facilitating a global shift in the energy industry characterized by a low-carbon, climatefriendly, and eco-responsible energy structure and smart energy services. China's energy industry will become more technologyand knowledge-intensive as well as highly integrated with the Internet, energy Internet, and Internet of Things. The national energy network will be complemented by regional and end-use energy networks. Smart grids, distributed power generation systems, and microgrids will be widely implemented. Smart manufacturing, smart building, and smart transportation will continue to inspire a structural change on the supply side. A diversified mix of options for energy supply and consumption will give rise to an integrated approach to the development of the energy industry that will reshape China's energy system.

A comprehensive range of long-term measures should be taken to bolster the fundamental role of energy engineering innovation and ensure that China's technological strengths in energy engineering and application can hold a leading position in the long run.

(1) The national energy plan emphasizes the clean and efficient utilization of fossil energy and large-scale development of nuclear and renewable energy, insisting on the collateral development of these two kinds of technology. Strategic planning for the integration of a diversified mix of energy sources is strengthened and next-generation energy technologies, the including energy Internet, are taken into consideration. The development of new energy technologies is supported by China's strategic planning for emerging industries. A national innovation fund for technical know-how and industry of disruptive energy will be set up.

(2) Existing energy S\&T resources should be consolidated to promote international big science plans and projects in the energy sectors in which China enjoys a leading position, such as coal, nuclear energy, and electricity. A series of key initiatives concerning the integration of a variety of energy sources and research projects such as the "integrated transparent detection of energy resources," "intelligent clean energy development," and "energy Internet" can be planned. National energy laboratories should be set up in Beijing, Shanghai, and Shenzhen, targeting cutting-edge, disruptive energy technologies as well as multidisciplinary basic research topics involving materials, information technology, and machinery. There is ongoing support for research efforts in energy strategy and technology policy. Highend think-tanks and large-scale market-based comprehensive energy research institutions will be set up and measures will be taken to nurture and support individuals and groups working on energy S\&T innovations. 
(3) Leading energy brands and companies should be encouraged to go global, offering internationally competitive products, equipment, and infrastructure in nuclear energy, coal, and electricity. Offshore energy technology markets and energy supply and transit hubs will be explored. An integrated approach will be taken to strengthen governance, regulation, and innovation policy in the energy sector. Further reforms in energy pricing will be launched in recognition of the nature of energy as a commodity. Natural resources consumption tax and environmental taxes (including carbon tax) will be introduced or improved. A series of initiatives can be established to promote responsible energy consumption, encourage energy-saving practices, and facilitate a shift to a clean, efficient, low-carbon, diversified market signaling system.

\section{Acknowledgement}

The support and help from the following project team members were invaluable in the preparation of this paper: Su Gang, Zhang Guosheng, Li Peng, Huhe Taoli, Cao Zhiguo, Wang Hongjian, Li Qiming, Guo Qifeng, Liang Kun, Fu Xiaopeng, and Fan Jingli.

\section{References}

[1] Research group on world's energy landscape change and energy production and consumption revolution. Strategy research reports on promoting energy production and consumption revolution, supported by the major consulting project of Chinese Academy of Engineering[R]. Beijing: Chinese Academy of Engineering, 2014. Chinese.

[2] Research group on the third industrial revolution and energy production and consumption revolution. Strategy research reports on promoting energy production and consumption revolution, supported by the major consulting project of Chinese Academy of Engineering[R]. Beijing: Chinese Academy of Engineering, 2014. Chinese.

[3] Chinese Institute of Engineering Development Strategies. Developing report on China's strategic emerging industries (2016) [M] Beijing: China Science Publishing \& Media Ltd (CSPM), 2015. Chinese.
[4] General Office of the State Council of the People's Republic of China. Energy development strategy action plan (2014-2020) [R]. Beijing: General Office of the State Council of the People's Republic of China, 2014. Chinese.

[5] National Development and Reform Commission, National Energy Administration of the People's Republic of China. Energy production and consumption revolution strategic action plan (2016-2030) [R]. Beijing: National Development and Reform Commission, National Energy Administration of the People's Republic of China, 2016. Chinese.

[6] British Petroleum. Statistical review of world energy, $2016[\mathrm{R} /$ OL]. [2016-10-20]. London: British Petroleum, 2016. http://www. bp.com/en/global/corporate/energy-economics/statistical-review-of-world-energy.html.

[7] Xie K C, Qiu Z J, Jin Q H, et al. Strategy research on nonconventional natural gas development and utilization in China [M] Beijing: China Science Publishing \& Media Ltd (CSPM), 2014. Chinese.

[8] Research group on the 13th Five Year Plan of new energy industry development. Research reports on fostering and developing strategic emerging industries in the 13th Five Year Plan period[R]. Beijing: Chinese Academy of Engineering, 2015. Chinese.

[9] Research group on engineering science and technology development strategy toward 2035 in energy and mining industry field. Research report on China's engineering science and technology development strategy toward 2035 [R]. Beijing: Chinese Academy of Engineering, 2014. Chinese.

[10] Xie K C, et al. Strategy research on clean, high-efficiency and sustainable coal development and utilization in China [M]. Beijing: China Science Publishing \& Media Ltd (CSPM), 2014. Chinese.

[11] China Association for Science and Technology. Subject development report on nuclear science and technology (2014-2015) [M] Beijing: China Science and Technology Press, 2016. Chinese.

[12] British Petroleum. BP energy outlook 2016 [R/OL]. (2016-09-12) [2016-11-10]. London: British Petroleum. http://www.bp.com/en/ global/corporate/energy-economics/energy-outlook-2035.html.

[13] International Energy Agency. World energy outlook 2016 [EB/ OL]. (2016-09-17) [2016-11-05]. http://www.iea.org/newsroom/ news/2016/november/world-energy-outlook-2016.html.

[14] Huang Q L, Peng S P. Research reports on fostering and developing strategic emerging industries in energy field [M]. Beijing: China Science Publishing \& Media Ltd (CSPM), 2015. Chinese. 